\title{
STUDIES ON INFLUENZA BY ANTIGENIC ANALYSIS
}

\author{
SeIHAChiro NIWAYAMA AND Mitsuo SHIBATA
}

Department of Bacteriology, Niigata University School of Medicine

Antigenic analysis was performed on many strains of A and B type influenza viruses isolated in Niigata Prefecture during the years 1962-69 and also on many prototype strains using cross hemagglutination-inhibition tests, antibody absorption techniques and cross neutralization tests.

Since 1957, continuous variations were observed in type B and most of A2 strains of influenza viruses isolated in Niigata Prefecture.

Furthermore, Hong-kong type Aichi/2/68 strain and Niigata/16/69, 60/69 strains which were isolated in epidemic of Hong-Kong type influenza in Niigata prefecture in the winter from 1968 to 69 were analysed antigenically by the same methods. It was shown that Aichi/2/68 strain was considerablly specific but related in a small degree with the A2 strains isolated before 1965, especially with Adachi/3/57 strain. Further it was found that there was more close relationship between the Niigata/16/69, 60/69 strains and A2 strains previously isolated.

\section{THE SUSCEPTIBILITY OF GEOGRAPHICAL RACES OF ONCOMERANIA NOSOPHORA TO INFECTION WITH JAPANESE LOCAL STRAINS OF SCHISTOSOMA JAPONICUM}

\author{
KAZUO YASURAOKA AND KUNIKo KOJIMA \\ Department of Parasitology, National Institute of Health, Tokyo
}

It is now generally recognized that the geographic strains of $S$. japonicum show different degrees of infectivity in various species of Oncomelania snails (Hunter et al., 1952; DeWitt, 1954;Pesigan et al., 1958; Vogel, 1958; Hsü et al., 1960; Moose et al., 1963, 1964; Chiu, 1967; Chi, 1969). Each geographic strain of $S$. japonicum infects, on the whole, best the Oncomelania species from its own endemic area, and to a lesser degree or not at all infects the snail species from the endemic areas of the other strains. In Japan the basin of the Chikugo River on Kyushu Island and the Kofu basin on Honshu Island have long been known as endemic areas of schistosomiasis japonica. Of interest is the question whether or not the Japanese strain of $S$. japonicum and its molluscan host, O. nosophora, are monotypic.

Our study involves introducing the $S$. japonicum miracidia from the two geo- 
graphic locations in Japan, Kyushu and Yamanashi, to infect (1) their geographically natural $O$. nosophora, (2) their geographically unnatural $O$. nosophora, and (3) the hybrid snail hosts.

Experiments were performed using both field collected and laboratory reared snails. The field collected snails had been proved negative from previous infection 3 months of repeatedly negative cercariae-shedding test in the laboratory. Snail exposures were made with miracidia from feces of experimentally infected dogs. Miracidia for exposure were used within one hour of hatching. Snails were exposed individually to 3 to 5 miracidia in small Petri dishes $(12 \mathrm{~mm}$ in diameter and $10 \mathrm{~mm}$ in height), allowing 16 to 18 hours for penetration.

Table 1. Showing the susceptibility of two geographical races (Kyushu and Yamanashi) of $O$. nosophora to infection with Japanese strain of

$S$. japonicum originated from Kyushu and Yamanashi

\begin{tabular}{|c|c|c|c|c|c|c|}
\hline $\begin{array}{l}\text { Source of } \\
\text { S. japonicum }\end{array}$ & $\begin{array}{l}\text { O. nosophora } \\
\text { from }\end{array}$ & $\begin{array}{c}\text { *Experiment } \\
\text { No. }\end{array}$ & $\begin{array}{l}\text { No. of } \\
\text { snails } \\
\text { exposed }\end{array}$ & $\begin{array}{l}\text { No. of } \\
\text { survivors }\end{array}$ & $\begin{array}{l}\text { No. of } \\
\text { survivors } \\
\text { infected }\end{array}$ & $\begin{array}{l}\text { Percentage } \\
\text { infection of } \\
\text { survivors }\end{array}$ \\
\hline \multirow{8}{*}{$\begin{array}{l}\text { Yamanashi } \\
\text { (Japan) }\end{array}$} & \multirow{4}{*}{$\underset{\text { Tosu }}{\text { Tyushu) }}$} & 1 & 50 & 42 & 39 & 92.8 \\
\hline & & 2 & 50 & 23 & 19 & 82.6 \\
\hline & & 3 & 42 & 23 & 22 & 95.7 \\
\hline & & $\quad * * 4$ & 52 & 39 & 15 & 38.5 \\
\hline & \multirow{4}{*}{$\underset{\text { (Yamanashi) }}{\text { Ryuoh }}$} & 1 & 50 & 48 & 5 & 10.4 \\
\hline & & 2 & 50 & 45 & 4 & 8.9 \\
\hline & & 3 & 42 & 13 & 0 & 0 \\
\hline & & $* * 4$ & 69 & 55 & 7 & 12.7 \\
\hline \multirow{6}{*}{$\begin{array}{l}\text { Kyushu } \\
\text { (Japan) }\end{array}$} & \multirow{3}{*}{$\begin{array}{c}\text { Tosu } \\
\text { (Kyushu) }\end{array}$} & 5 & 117 & 101 & 85 & 84.2 \\
\hline & & 6 & 12 & 10 & 7 & 70.0 \\
\hline & & $* * 7$ & 55 & 44 & 38 & 86.4 \\
\hline & \multirow{3}{*}{$\underset{\text { (Yamanashi) }}{\text { Ryuoh }}$} & 5 & 117 & 96 & 1 & 1.0 \\
\hline & & 6 & 12 & I1 & 0 & 0 \\
\hline & & $* * 7$ & 69 & 48 & 5 & 10.4 \\
\hline
\end{tabular}

* Experiments bearing the same number were performed on the same day using miracidia from the same pool of schistosome eggs.

** Laboratory bred snails.

After exposure, the snails were kept in clay pots which contained moistened mud at room temperatures varying between 16 and $28^{\circ} \mathrm{C}$. Small amounts of rice flour were added at intervals of a few days. Ninety days after exposure the snails were crushed to determine infection. Tests were made in seven series and each series was made on the same day with miracidia from the same batch. The results of the preliminary experiments are summarized in the table.

Although the rates of infection varied from one experiment to another, $O$. nosophora from Kyushu was highly susceptible to infection with both $S$. japonicum from Kyushu and Yamanashi. An interesting and unexpected result was that $O$. nosophora from Yamanashi was less susceptible or rather refractory not only to 
S. japonicum from Kyushu but also to $S$. japonicum from Yamanashi. It is difficult to say why $O$. nosophora from Yamanashi was less susceptible to its geographically natural $S$. japonicum. The susceptibity of the hybrid snails to $S$. japonicum from Kyushu and Yamanashi is at present being investigated and will be reported upon later.

\title{
RELATION BETWEEN THE PREVALENCE OF CULEX TRITAENIORHYNCHUS AND THE EPIDEMIC OF JAPANESE ENCEPHALITIS
}

\author{
YoshITo WADA AND NANZABURO OMORI \\ Department of Medical Zoology, Nagasaki University School of Medicine
}

There was examined the relation between the epidemic of Japanese encephalitis and the prevalence of its main vector, Culex tritaeniorhynchus, in different areas of Japan, by using various statistics. Here, the time of the epidemic in each area was considered to be well represented by the time when the rate of HI antibody in slaughtered hogs exceeds $50 \%$. And, the prevalence of C. tritaeniorhynchus was considered to be influenced by (1) the temperature which is related to the developmental speed of the mosquito, (2) the area of paddyfields which are the main breeding place of the larvae, and (3) the transplanting time of the rice-plant when the water-lodged surface area of paddyfields reaches maximum. So, the relations of the time of the $\mathrm{HI}$ antibody of slaughtered hogs reaching over $50 \%$ to the temperature, the area of paddyfields, and the time of transplanting of rice plants were examined for each year from 1965 to 1969, and the followings were pointed out. Generally, the time of exceeding $50 \%$ in HI antibody of the hogs occurs earlier in southern areas where temperature becomes higher in early season, and vice versa. However, there are some areas where the time of exceeding $50 \%$ in the antibody is much earlier or later than that expected from the temperature conditions of the areas. In many of these areas, the time of reaching $50 \%$ in $\mathrm{HI}$ antibody of slaughtered hogs seems to have an close relationship to the time of transplanting of the rice plant. The area of paddyfields seems not to influence much on the time of reaching $50 \%$ of the antibody. From the above, it may be concluded that there is a close relation between the time of the epidemic of Japanese encephalitis in hogs and the active time of $C$. tritaeniorhynchus breeding which is promoted mainly by the temperature, and sometimes by the time of the transplanting of the rice plant. 